\title{
Some Thoughts about Literature as a Means of Advancing Sustainable Unity and Stability in the Contemporary Nigerian State
}

\author{
Anaso, George Nwaorah \\ Department Of Language And Communication Studies \\ Federal University, Dutsin-Ma, Katsina State \\ Nwabudike, Christopher Eziafa (Corresponding Author) \\ Department Of Language And Communication Studies \\ Federal University, Dutsin-Ma, Katsina State \\ E-mail: cnwabudike@fudutsinma.edu.ng
}

Doi:10.7575/aiac.alls.v.5n.3p.143

Received: 05/04/2014

URL: http://dx.doi.org/10.7575/aiac.alls.v.5n.3p.143

Accepted: 15/05/2014

\begin{abstract}
An in depth investigation was conducted on the possibility of literature employed to enhance cohesion, sustainable unity, national stability and security of lives and property in the contemporary Nigeria. These three elements- Unity, national stability and security of lives and property are considered the key-pillars of a modern state, the absence of which render the Country volatile and uninhabitable. The contemporary Nigeria lacks these elements in a large dose, thereby rendering it a country without peace and security. This has been the root cause of the current nationwide agitation for a national conference required to define the future for a country that has existed for a century, but still grappling unsuccessfully, with the problems of nationhood. This paper identified the cause of the problems to arise from the multi-ethnic composition of the one-hundred and seventy million people and over three hundred different ethnic nationals of Nigeria. The fact of uniting so many ethnic groups into one country is not peculiar to Nigeria, as many other countries have a similar composition.
\end{abstract}

Keywords: Literature, Sustainable unity, Stability, Nigerian state

\section{Introduction}

Literature is mainly viewed as the study of works of literary creation that employ both facts and fiction to make postulation about man and his society (Monk 1985:17). In this way, Literature is a unique and prodigious discipline that incorporates literary, artistic, cognitive, historical, sociological, psychological and creative faculties into one coordinated operative mode. This statement is in agreement with Crompton (1969:122) that, 'Literature is the melting pot of various academic disciplines, yet very distinct from all that have contributed to its make up'.

Literature in the early times was seen in terms of European creative words of writers like Chaucer, Volpone, Shakespeare, Swift, Dickens etc. Literature originates from culture and brings out the best of cultural heritage in terms of both aesthetic and ethical values. Hence, the study of literature as a discipline has been defended in terms of its capacity to:

i. Give students a better understanding of the language in which it is written;

ii. Develop the character of the students because in literature, much attention is given to the understanding of text and plot narration of novels and/or paraphrasing of poems which equips the learners with the understanding of literary works and development;

iii. Finally, the study of literary text exposes the learner to the lives, characters and activities of men and women in a particular milieu and through their reaction to their environment, the student learn much about human behaviour in varying situation in response to their circumstances in life.

Literature is therefore understandably studied for its civilising value on the learner; and this is imparted through the understanding of the text from its themes, plots and characterization. In this way, it can create a better citizen because it influences our attitude to life and people in general. Again, through literature, cultural lives of various ethnic groups are exposed to other parts of the world, and this enhances the understanding and awareness of mankind about the various human experiences from other parts of the globe.

Literature can therefore, be said to expose the reader to the real lives of men and women in various situations in life; and these situations simulate our peculiar situation and circumstances. Through these depictions, we tend to see and understand better from what we are shown- our lives and the lives of other people around us. However, all this will transpire for only those who read or study literature. 
What constitute Nigeria's problems are the following factors.

i. Absence of genuine interest and desire for unity among the federating units that make up Nigeria. This has the verisimilitude of forcing people into an unwelcome or unaccepted polygamous marital life with crises erupting every now and then;

ii. Total lack of the spirit of oneness to a common cause and background, a major uniting factor;

iii. Deep-rooted and irreconcilable cultural and religious differences from which arose mutual hatred and suspicion right from the on-set;

iv. Finally, the pervasive illiteracy and ignorance identifiable among the majority of the country's population, especially in the rural areas.

The country's literatures -both traditional and modern- do not emphasise the need for a united country, nor do they elicit a common literary background for the citizens to draw lessons on unity, stability, security and patriotism from. Having drawn attention to these obvious problems, this paper goes ahead to conclude that Nigerians cannot advance unity in the country unless a new brand of Literature is evolved to handle literary education of the citizenry, covering all those missing elements in the psych and the mindset of the citizenry. This area of emphasis is given as the recommendations of this paper.

\section{Literature And Storytelling}

African Literature has its origin in the oral tradition which is expressed in various forms like folktales, ballads, fables, poems, chants, songs and others. By means of oral tradition, the aspects of African cultural life that could not be recorded in writing have been given authenticity and scripted to enable the present generation to redefine its roots and ancestry, using these traditional literary forms mentioned. It is for the above reason that Achebe, in Anthills of the Savannah strongly emphasises on the importance of storytelling which is an oral literary form, in the community:

...it is only the story that can continue after the war and the warrior. It is the story that outlines the sound of war drums and exploits of brave fighters. It is the story, not the others, that save our progeny from blundering like blind beggars into the spikes of the cactus fence...the story is our escort, without it, we are lost. (Achebe 1985:124)

From the above, we can acknowledge the role of literature in nation-building, especially in the traditional society. At various times in their history, all human societies depended on their oral tradition to peep into their cultural past. Even the English society did not become literate until early $15^{\text {th }}$ century when English language became written and adopted as the medium of teaching and official communication in England. It was then that literary works were flourished, especially with such works as Beowulf etc which were oral works (though epic poems).

As in all cultures across the globe, Nigerian (and African literature in general) originated from the embers of its oral tradition, and drew from their established cultural traditions. There is no human community that has no cultural life, as against the claims of Western Europe during the era of slave trade so as to justify slavery. According to Nkrumah (1957):

The history of Africa as presented by European scholars had been encumbered with malicious myths. It was even denied that we were a historical people. Such disparaging accounts had been given of African societies and their culture as to justify slavery, and slavery posed against these accounts seemed a positive deliverance of our ancestors. (pg 18)

African cultural life is replete in the literary works written by African writers. It is basically along this line that Achebe explains his motive for the novel Things Fall Apart (1958)

...a purpose implicit or expressed, to correct the distortions of West African cultures, to recreate the past in the present in order to educate the West African reader and give him the confidence in his cultural heritage which had been eroded by colonialism, and also in order to help him to get rid of the false impression about the West African cultures acquired from centuries of cultural misrepresentation (Obiechina, 1972:244).

From the references about Africans above elucidated from works of African writers, one can only agree strongly with Oke (1972) in justifying the role of literature as 'the total expression of the universal man, of eternal truths, not just a chronicle of a civilisation, (pg 73), because it establishes mankind's full humanity and cultural heritage.

\section{Literature And Citizenship}

Civilisation according to Hawkins is the totality of the cultural heritage of a human race, including the historical past, the present and the future in anticipatory perception $(1982: 17)$. This forms and determines the world view and behavioural pattern of every individual within the race to which he or she is expected to conform with, to be accepted in the enclave. If any member fails to conform to these established norms or attitudinal patterns, he or she will be regarded as a deviant and will be sanctioned in various ways according to established social order or norm. When Achebe, in Things Fall Apart, writes that Africans did not hear of culture for the first time from the white men, but that the white men met Africa's cultural heritage well established in Africa when they first came to the scene, customs and traditions were seen in proper operation in the setting of the novel which captured the life in the community before the coming of the missionaries. 
The coming of the Europeans rather than bring civilisation to the multiplicity of tribes in their various cocoons shocked and dismantled various nations from their serene existences, truncated and welded them to other ethnic nationalities that they had nothing in common with (Avery 1972:116). All these were achieved by the colonisers by sheer brute force purposely 'for the economic interest of the colonising powers and not as ostensibly claimed for the interest and benefits of the people concerned.'(Shittu 1981:76)

Colonialism dismantled the original social and political system of African nationalities and imposed strange and or forced nationalities on different nations that had no prior social, cultural and political affinities. Furthermore, strange political experiences of the colonisers were imposed on these welded strange bedfellows, all in the effort to subjugate them to one single entity easier to rule. This became the colonially imposed institution which the colonised people tried to live with and survive, the crisis that arose from this political experience is described by Davidson (1992:10-12) as 'the crisis of institution - a nationalism that started as nationstatism before colonialism'. The unfortunate thing about Africa's colonial experience is that all through, all the welded various nationalities still owed allegiance to their different ethnic or national origins both within and outside the circumscribed borders of their colonially prescribed boundaries.

In 1914, what became known as Nigeria today was an offshoot of the amalgamation of Northern and Southern protectorates which became forcefully merged into one country, despite the flurry of social and cultural differences among the various groups as well as various protests from the people against this political merger. Before long, it became axiomatic to the colonisers that their dream of a united country was a mere exercise in futility because unity could not be achieved by this kind of artificial or meddlesome exercise. However, through a system of divide and rule (Shittu, 1981), this parched up territorial amalgamation was kept up by intrigue while the colonialist planned and granted the delicate country a mock independence in 1960.

Literature of Nigeria which has no defined unity has not done much to educate Nigerian citizenry on nationalism or patriotism. This is because of the following reasons:

i. The citizenry up to this moment do not understand these terms because they always look up to and fall back on their ethnocentric backgrounds;

ii. There is no common acceptable ideological framework politically, socially or culturally for the entire citizenry;

iii. There is deep-rooted mutual suspicion among the various ethnic citizenry, which has become expressed in various forms and intensities. These are the origins of various conflicts that the country has become engulfed in over the years of its existence, without much visible sign of abetting.

\section{Citizenry And Conflict}

Literature can hardly be said to have any positive influence on the moulding of the Nigerian character for the reason that the so called Nigerian literary works are not directed at character formation or nation-building. Apart from Nigeria's folklore whose didactic aspects have little or no impact on the generality of the people, the post colonial writings are directed at providing insight into the country's social and political life, with little or no inference drawn from cultural ethics. For the reason, these writings do not equip the citizenry with sufficient moral and spiritual force and enablement to tackle the problems associated with nationalism. People still cling to their parochial origin firmly in all cases.

Usually, any national problem that arises is viewed from the narrow ethnic parochial perspective. There is totally lack of universal rallying forum and perspective for evolving true solution for any national problem. It is for this reason that there has been the tendency towards formation of various ethnic militant bodies whose activities are rooted in destabilising the polity in order to protect the parochial interests of individual groups. There is therefore a frequent upsurge in ethnocentric agitations based on mutual suspicion among the various groups. Viewing the belligerent posture of the society, the situation can only be described in the words of Heraclitus: 'deliberate violence is more difficult to be quenched than fire'. The attritive nature of ethnocentric conflict in various African countries points to this statement.

Underlying all ethnic squabbles, rancour and belligerence in Nigeria is the absence of true patriotism over a political structure that no one evidently appears to believe in. Not even the political leaders who are more interested in feathering their own nest are truly patriotic. Hence, Otu (2002) notes that the formation of such ethnic-based militant groups as OPC, MEND, NECO, MASSOB, BOKO HARAM and others is aimed at securing each group's interest. The spirit of true nationalism is totally lacking.

Lack of patriotism has also accounted for the absence of an acceptable national constitution, other than that parched document that has become difficult to adopt as a complete constitution. Some people are carried away by the sentimentality of celebrating a century of nationhood without counting the cost. Yet a hundred year old country is still wobbling gingerly like a baby learning to walk.

\section{Citizenry And Security}

Lack of genuine unity, patriotism and disbelief in national project, coupled with the militancy of various ethnic groups in the country has rendered the country ungovernable and difficult to defend, and made it a suspect security-wise. At this particular moment, there is an insurgency in parts of the country's North-eastern part, constraining the President to declare a state of emergency and deploying troops to quell the insurgency. This situation could not have arisen without the tacit support of the people there. Also, collaboration of the South-western area with neighbouring countries has 
given the country's leaders a reason to feel disturbed by the infringement of the country's territorial integrity through incursion from the neighbouring Republic of Benin.

It will be recalled that in two troubled spots, colonial boundary demarcations have not been effective because various ethnic nationalities were truncated and separated into different countries. Such is also the case in South-eastern part of Bakassi area where Nigeria and Cameroon have been made to share one ethnic group because of the presence of Nigeria's mineral oil between themselves, despite the protests from the affected tribes that they want to join their kins in Nigeria. Colonial experience has therefore completely been the source of political instability and resulted in the complete inability of various countries in managing their security challenges. It is neither literature, religion, shared social experiences nor culture that has been able to provide a strong bulwark to hold the country together against turbulent centrifugal forces of disintegration which often overwhelms the weak centripetal beginnings of most countries in Africa, according to Barkin (2000:36).

\section{Conclusion}

Heraclitus is of the view that the chain of wedlock is often too heavy that it takes two and sometimes three to carry it. A federation of different ethnic nationalities is like a marriage of all the federating units and a burden of the union is usually irksome and uncomfortable to the federating units. When this happens, the parched up union will not depend on what one party provides to sustain it, while the other units will be seen as parasites living unremittingly on proceeds from others. When this situation has existed for as long as a century on a parched up unity, she should begin to explore other options of relieving tension and allowing the units access to self determination rather than tenaciously clinging on unity in self deceit, which at best ends up in a time-bomb that may blow them to cinders.

It is the view of this paper that the brand of Literature we have in Nigeria now can provide a veritable source of enhancing unity and providing security in a nation state that shares similar culture, religion and social experience and affinity, rather than in a multi-national state with different cultural experiences and nothing else to hold them together than colonial legacy. To borrow from Achebe's writing, when things fall apart, the centre cannot hold them together.

\subsection{Recommendation}

After a thorough consideration of the political, social and literary issues involved in nation building with particular reference to Nigeria as a developing society, a number of inferences have been drawn. These form the basis of the following recommendation.

i. Creation of a new brand of Nigerian Literature that will capture the educational, political, ethical and nationalistic needs of the country in terms of unity, stability and security of lives and property of the citizens;

ii. Meaningful and sincere national dialogue or conference on the future of the country, free from undue interference of external interests and conducted in a free and fair manner should be conducted;

iii. Enforcement of the study of two of the three major languages of Nigeria and their Literatures in every region where such languages are not spoken. This will enhance unity and esprit de corps in the body politics of the country.

The creation of a new brand of Literature will serve as a force to drive the spirit of patriotism, nationalism and stability, while driving away sectional or parochial self interests of the ethnic groups. Cultural differences among the various ethnic groups are responsible for this ugly trend and traditional Literature alone cannot undo these nor ensure the unity and stability of the country.

\section{References}

Achebe, C. (1958): Things Fall Apart. London: Heinemann.

Achebe, C. (1985): Anthills of the Savannah. London: Heinemann.

Avery, P.H. (1972): A Short History of West Africa,second edition. Freetown; Pendullum Press.

Barkin I. F. and Barkin, S. T. (2001): Africa's Struggle for Unity and Liberation. Accra: Cannon Press.

Crompton, O. P. (1989): Studies in Literary Appreciation. Westham: Citadel.

Davidson, B. (1992): The Blackman's Burden. Ibadan: Spectrum.

Vassah, G. (1975): Equiano's Travels (AWS). London: Heinemann

Hawkins, S.P. (1983): Interpreting and Constructing Life. Ibadan: Arrow Press.

Monk, S. G. L. (1991): Literature and Arts in the African World. Nairobi: Morgan.

Nkrumah, K. (1957): Conscience. Accra: Government Press.

Obiechina, E. (1975): Culture, Tradition and Security in the West African Novels. Cambridge: C.U.P.

Oke, D.O. (1972): 'Some Thoughts on the Function of Literary Criticism in Nigeria and Education'. Journal of the English Studies Association, Vol 5; Nos 1 and 2.

Otu, S. (2002) : Nigerian Unity: With or Without Stability? Lagos: Jide Press.

Plaatje, Sol. T. (1930) : Mhudi. Johannesburg: Quaggah.

Shittu A. B. (1991): Colonialism and the African People Ibadan: Olumide Press. 